\begin{tabular}{lcccr} 
T H E & A R C H I V E & O F & M E C H A N I C A L & E N G I N E E R I N G \\
\hline VOL. LVIII & 2011 & Number 1
\end{tabular}

10.2478/v10180-011-0001-y

Key words: soaring flight, minimum-time problem, pseudospectral Chebyshev's method

\title{
OPTIMIZATION OF GLIDER'S TRAJECTORY FOR GIVEN THERMAL CONDITIONS
}

The minimum-time problem for a glider flying in the vertical plane is considered. The glider is regarded as a particle moving in the atmosphere in given thermal conditions. The problem is formulated in optimal control and solved using direct pseudospectral Chebysev's method. The data are taken for the Word Class Glider PW-5 "Smyk". Computed optimum results are compared with glider's trajectories from the Second Domestic Glider Championship 2006, Suwałki, Poland.

\section{NOMENCLATURE}

$\mathrm{C}_{x}-$ drag coefficient,

$\mathrm{C}_{z}-$ lift coefficient,

$\mathrm{h} \quad-$ altitude of flight [m],

g - gravitational acceleration $\left[\mathrm{m} / \mathrm{s}^{2}\right]$,

$\mathrm{J} \quad-$ performance index $[\mathrm{s}]$,

$\mathrm{m}$ - mass of the glider $[\mathrm{kg}]$,

$\mathrm{P}_{x}-\operatorname{drag}[\mathrm{N}]$,

$\mathrm{P}_{z}-\operatorname{lift}[\mathrm{N}]$,

$\mathrm{S}-$ wing area $\left[\mathrm{m}^{2}\right]$,

$\mathrm{t} \quad-$ time [s], independent variable,

$\mathrm{u} \quad-$ horizontal air velocity (wind velocity) $[\mathrm{m} / \mathrm{s}]$,

$\mathrm{V} \quad-$ airspeed $[\mathrm{m} / \mathrm{s}]$,

* Ph.D. student of Faculty of Power and Aeronautical Engineering, Warsaw University of Technology; e-mail: krogowski@meil.pw.edu.pl

** Institute of Aeronautics and Applied Mechanics, Warsaw University of Technology; e-mail: maron@meil.pw.edu.pl 


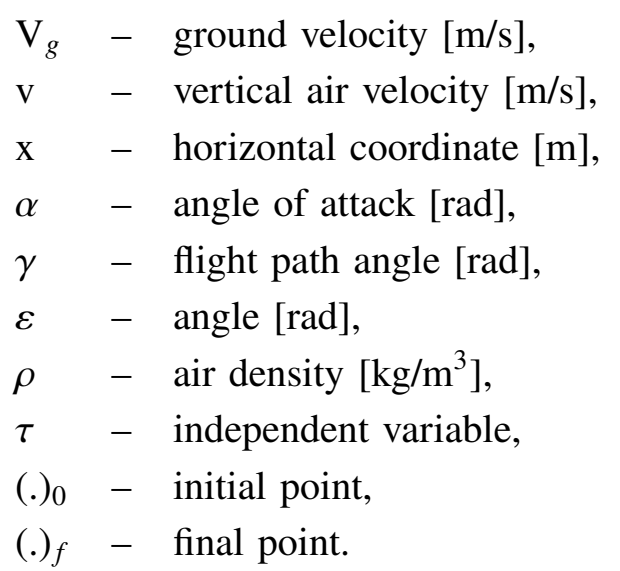

\section{Introduction}

Application of calculus of variations to the dynamics of atmospheric flight extends to early fifties when the minimum-time-to-climb problem was considered (Rutowski, 1954; Clancy, 1975). The piston-engine aircraft having greater altitude had an advantage over the enemy up to the end of the World War the Second. Introduction high-performance jet-propulsion aircraft, that took place just after the $2^{\text {nd }}$ world war, showed that not only the potential energy of the aircraft should be considered, but also the total energy including the kinetic one (the so-called energy height method). The spectacular result of this approach is, as indicated there, that the fighter should rapidly dive through the transonic region, and subsequently zoom to the ceiling. During such a maneuver, the fighter operates using its maximum thrust. That analysis assumes that the kinetic and potential energy can be interchanged instantaneously without losses of energy. The next impulse for development of these methods in dynamics of atmospheric flight was the first fuel crisis from the beginning of the seventies. The minimum-fuel problem was considered (Maroński, Lucjanek, 1979). In this problem, the thrust is an additional control variable and it is not maximum during the whole maneuver. Two theoretical difficulties appear: the optimum thrust may be of "chattering" type, where the average values of the thrust are not optimal, or the controllers are on the so-called singular arcs, where the thrust attains a value lower than the maximum one, but classical necessary conditions of optimality do not hold (Maroński, 1988). The effectiveness of the computational methods is important for practical applications. For several years, the attention was focused on the indirect numerical methods basing, for example, on Pontryagin's maximum principle. In the opinion of the authors of the paper, this group of methods is often ineffective - they are ill-conditioned. Moreover, it 
is difficult to consider inequality constrains imposed onto the state variables. Over the last decades, the progress in development of direct methods happened. These methods employs polynomial approximation for the state and control variables and the optimal control problem has been converted into a nonlinear programming one. The paper by Panasz and Maroński (2005) shows that such an approach is effective for commercial aircraft trajectory optimization, as it minimizes the direct operating costs. The present paper presents the extension of previous author's experience for the case of optimal soaring flight where the thrust disappears, however, where there are relatively rapid variations of wind and air-current patterns.

\section{Problem formulation}

The winner in a soaring event is the pilot covering the given distance in minimum time. The performance index is in the form that is minimized

$$
J=\int_{0}^{t_{f}} 1 d t=t_{f} \Rightarrow M I N .
$$

Fundamental assumptions of the model are:

1. The glider is regarded as a particle. Its dimensions are negligible in comparison with the covered distance.

2. The motion is in the vertical plane. The circulations in thermals are not considered.

3. The Earth is regarded as an inertial system. It is flat and gravitational acceleration is constant.

4. The gliders velocities are low compared with Mach number, the flow is regarded as incompressible.

5. The air density varies with altitude according to the Standard Atmosphere.

6. The vertical and horizontal air velocities are considered. They are given and they may vary with the distance and altitude.

7. The glider is controlled via variations of its angle of attack. The equilibrium of moments about the axis perpendicular to the plane of motion is automatically satisfied. The ballast is not dropped during the flight. Different masses may be considered, however.

The equations of motion of the sailplane resulting from the Newton's second law in natural coordinate system are as follows (Maroński and Lucjanek, 1979; Panasz and Maroński, 2005):

$$
m \frac{d V_{g}}{d t}=-P_{x} \cos \varepsilon-P_{z} \sin \varepsilon-m g \sin \gamma,
$$




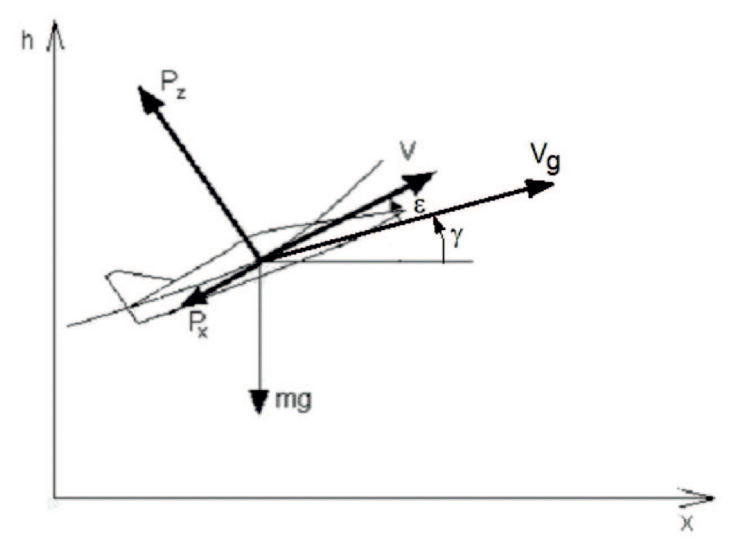

Fig. 1. Forces exerted on the glider

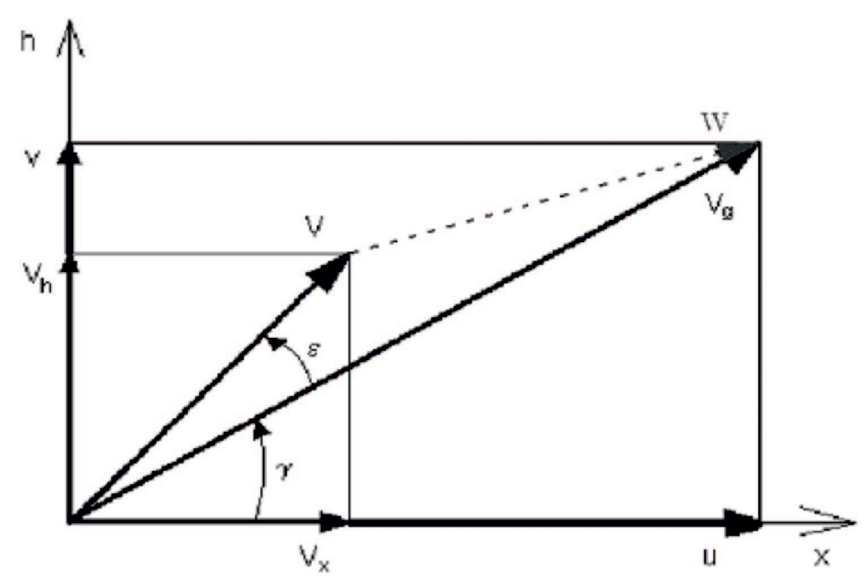

Fig. 2. Wind model

$$
m V_{g} \frac{d \gamma}{d t}=P_{z} \cos \varepsilon-P_{x} \sin \varepsilon-m g \cos \gamma
$$

They should be supplemented by kinematical relations:

$$
\begin{aligned}
& \frac{d x}{d t}=V_{g} \cos \gamma, \\
& \frac{d h}{d t}=V_{g} \sin \gamma,
\end{aligned}
$$

where the aerodynamic forces are:

$$
P_{x}=0.5 \rho(h) V^{2} S C_{x}(\alpha), \quad P_{z}=0.5 \rho(h) V^{2} S C_{z}(\alpha),
$$

and the geometrical relations resulting from Fig. 2 are:

$$
V^{2}=V_{g}^{2}-2 V_{g}(u \cos \gamma+v \sin \gamma)+u^{2}+v^{2},
$$




$$
\varepsilon=\sin ^{-1}\left[\frac{1}{V}(u \sin \gamma-v \cos \gamma)\right] .
$$

The air density $\rho$ is a given function of altitude $\mathrm{h}$, and aerodynamic coefficients $\mathrm{C}_{x}, \mathrm{C}_{z}$ of angle of attack $\alpha$.

As we use the nomenclature known in optimal control, the equations (2)-(5) are the state equations, $\mathrm{V}_{g}, \gamma, \mathrm{x}, \mathrm{h}$ are the state variables. The control variable is the angle of attack $\alpha$ that is an unknown function of time (or covered distance) and it is optimized.

The state equations should be supplemented by boundary conditions representing the state of the system at the beginning and at the end of the event:

$$
\begin{array}{ccc}
V_{g}(0)=V_{g 0}, & h(0)=h_{0}, & x(0)=x_{0}, \\
V_{g}\left(t_{f}\right)=V_{g f}, & h\left(t_{f}\right)=h_{f}, & x\left(t_{f}\right)=x_{f} .
\end{array}
$$

These values are given. The boundary conditions are not imposed onto the flight path angle $\gamma$, because the authors have no records of these values from the event. These conditions are free and they follow from optimization procedure. The computational code is very flexible, therefore different problem formulations are possible.

The problem is stated as follows. Find the angle of attack $\alpha$ as a function of time to minimize the time of the event $\mathrm{t}_{f}$ given by the functional (1). The value of $\alpha$ should be lower than its maximum value - the stalling angle. The state equations (2)-(5) with the boundary conditions (6), (7) should be satisfied. The inequality is also imposed onto the altitude $h$ that should be positive.

\section{Method}

The problem formulated above is a typical problem of optimal control: find the control function vector $\mathrm{u}(\tau)$ and the corresponding state trajectory vector $\mathrm{x}(\tau)$ minimizing the performance index (cost function, objective function) described by Bolza

$$
J\left[x(\cdot), u(\cdot), \tau_{f}\right]=M\left[x\left(\tau_{f}\right), \tau_{f}\right]+\int_{\tau_{0}}^{\tau_{f}} L[x(\tau), u(\tau), \tau] d \tau .
$$

In the presented approach, the dynamic constraints are given in the form of differential inclusions (Fahroo and Ross, 2002; Rogowski, 2007)

$$
f_{l} \leq f[\dot{x}(\tau), x(\tau), u(\tau), \tau] \leq f_{u}, \quad \tau \in\left\langle\tau_{0}, \tau_{f}\right\rangle .
$$


This is a generalized formulation, therefore, if we set the lower $\mathrm{f}_{l}$ and upper $\mathrm{f}_{u}$ bounds equal to zero, we obtain differential algebraic equations

$$
f[\dot{x}(\tau), x(\tau), u(\tau), \tau]=0, \quad \tau \in\left\langle\tau_{0}, \tau_{f}\right\rangle .
$$

Furthermore, if we assume that the Jacobian $\partial f / \partial \dot{x}$ is nonsingular, the equation (10) may by transformed into the ordinary differential equation

$$
\dot{x}(\tau)=f[x(\tau), u(\tau), \tau], \quad \tau \in\left\langle\tau_{0}, \tau_{f}\right\rangle .
$$

Moreover, the boundary conditions may be considered in the form

$$
\psi_{l} \leq \psi\left[x\left(\tau_{0}\right), x\left(\tau_{f}\right),\left(\tau_{f}-\tau_{0}\right)\right] \leq \psi_{u},
$$

where $\psi_{l}$ and $\psi_{u}$ are constant vectors representing the lower and upper bounds of inequalities. The state and control constraints are formulated in the form

$$
g_{l} \leq g[x(\tau), u(\tau), \tau] \leq g_{u} .
$$

As above, in the case of equality constraints, the lower and upper bounds must equal.

The Chebyshev pseudospectral method is applied in this paper. It is a particular case of a more general class of spectral methods. These methods involve two steps: in the first one we choose a finite-dimensional space from which an approximation to the solution of the differential equation is made, and in the next one we select a projection operator, that imposes the differential equation in a finite-dimensional space. In spectral methods, the underlying polynomial space is spanned by orthogonal polynomials, which are infinitely differentiable global functions. Legendre and Chebyshev polynomials are examples of these orthogonal polynomials, which are orthogonal on the interval $[-1,1]$. The functions are expanded in terms of interpolating polynomials, thus the expansion coefficients are the values of the function at the node points. Because an arbitrary choice of node points can give very poor results in interpolation, different Gauss quadrature points are chosen to improve the accuracy in interpolation of a function. The derivatives of interpolating polynomials at node points are given by a differentiation matrix.

In the applied method, the interpolation points are in the form

$$
t_{k}=\cos (\pi k / N), \quad k=0 \ldots \ldots, N .
$$

These points belong to the interval $[-1,1]$ and they are the extrema of the Nth-order Chebyschev polynomial $\mathrm{T}_{N}(\mathrm{t})$. The jth-order Chebyshev polynomial is as follows

$$
T_{j}(t)=\cos (j \arccos t), \quad j=0 \ldots \ldots, N,
$$


which yields

$$
T_{j}\left(t_{k}\right)=\cos (\pi k j / N) .
$$

State and control variables are approximated by polynomials

$$
\begin{aligned}
& x^{N}(t)=\sum_{j=0}^{N} x_{j} \phi_{j}(t), \\
& u^{N}(t)=\sum_{j=0}^{N} u_{j} \phi_{j}(t),
\end{aligned}
$$

where

$$
\phi_{j}(t)=\frac{(-1)^{j+1}\left(1-t^{2}\right) \dot{T}_{N}(t)}{N^{2} c_{j}\left(t-t_{j}\right)}, \quad \mathrm{j}=0,1 \ldots \ldots \ldots . . .
$$

are the Lagrange interpolating polynomials of order $\mathrm{N}$, with

$$
c_{j}=\left\{\begin{array}{cc}
2 & j=0, N \\
1 & 1 \leq j \leq N-1
\end{array} .\right.
$$

The Lagrange polynomials satisfy the condition

$$
\phi_{j}\left(t_{k}\right)=\left\{\begin{array}{lll}
1 & \text { if } & j=k \\
0 & \text { if } & j \neq k
\end{array} .\right.
$$

Therefore, it follows that

$$
x^{N}\left(t_{k}\right)=x_{k}, \quad \text { and } \quad u^{N}\left(t_{k}\right)=u_{k} .
$$

It means that the node points are the interpolating points.

Because the node points lie in the computational interval $[-1,1]$, the problem should be transformed into this interval by the linear transformation for $t \in\left[t_{0}, t_{N}\right]=[-1,1]$

$$
\tau=\left[\left(\tau_{f}-\tau_{0}\right) t+\left(\tau_{f}+\tau_{0}\right)\right] / 2 .
$$

Further details of how to express the derivative $\dot{x}^{N}(t)$ in terms of $x^{N}(t)$ at the node points $t_{k}$ and on the cost function discretization using Clenshaw-Curtis quadrature scheme one can find in Fahroo and Ross (2002).

Summing up, the optimal control problem described by relations $(8,9$, $12,13)$ is approximated by the following nonlinear optimization problem: find coefficients $X=\left(x_{0}, x_{1}, \ldots, x_{N}\right), U=\left(u_{0}, u_{1}, \ldots, u_{N}\right)$, and final time $\tau_{f}$ to minimize performance index (8). For solution of the minimum-time soaring problem, this method has been implemented in MATLAB employing a sequential quadratic programming algorithm (MATLAB Optimization Toolbox, 2000; Trefethen, 2000; Zalewski and Cegieła, 2002). 


\section{Results}

All computations refer to the Word Class Glider PW5 "Smyk". The data are as follows (Instrukcja użytkowania w locie szybowca PW-5 „Smyk”, 2001; Obciążenia struktury szybowca PW-5 "Smyk", 1993): wing area $10.16 \mathrm{~m}^{2}$, mass of the glider $230 \mathrm{~kg}$, lift curve slope $\mathrm{dC}_{z} / \mathrm{d} \alpha=5.8490$, stalling angle $\alpha_{c r}=12 \mathrm{deg}$. The polar curve of the glider is depicted in Fig. 3.

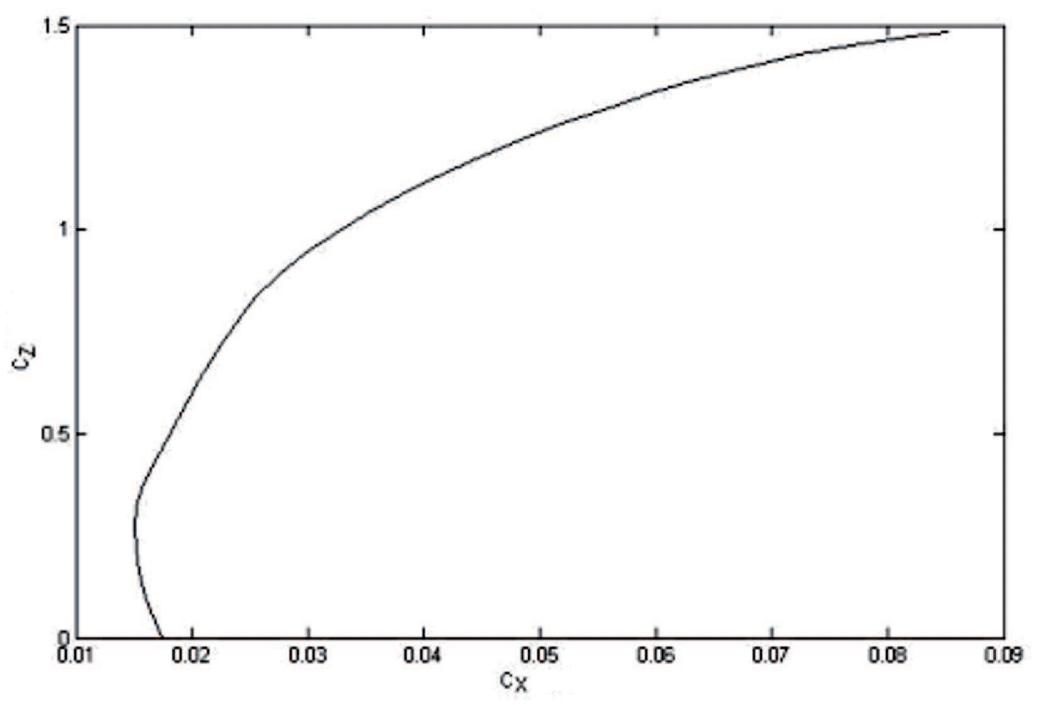

Fig. 3. The polar curve of the Word Class Glider PW-5 "Smyk"

The number of nodes influences the accuracy of computations on the one hand, and the computing time on the other hand. During preliminary computations, the optimal results have been compared one to another for different node numbers $\mathrm{N}=8,11,14,17,20,60$. In author's opinion, the node number $\mathrm{N}=25$ is a rational compromise between the computing time and the accuracy. For PC Pentium 4 class $(3.08 \mathrm{GHz}, \mathrm{RAM} 1 \mathrm{~GB})$ the computations for $\mathrm{N}=8$ take a few minutes, for $\mathrm{N}=20$ a dozen or so minutes, and for $\mathrm{N}=6.0$ some hours.

The optimal flight trajectory has been compared to the real trajectory covered by the pilot Marek N. during the Second Domestic Glider Cham- pionships, Suwałki, Poland 30.06-09.07.2006 (http://zawody.aeroklub.suwalki.pl /kzs2006/wyniki.php). The computed optimum velocity is greater than the real one. The real thermal conditions have not been known, however. The diagram of the real altitude versus distance (Fig. 7) suggests that there was a thermal near the final point. 


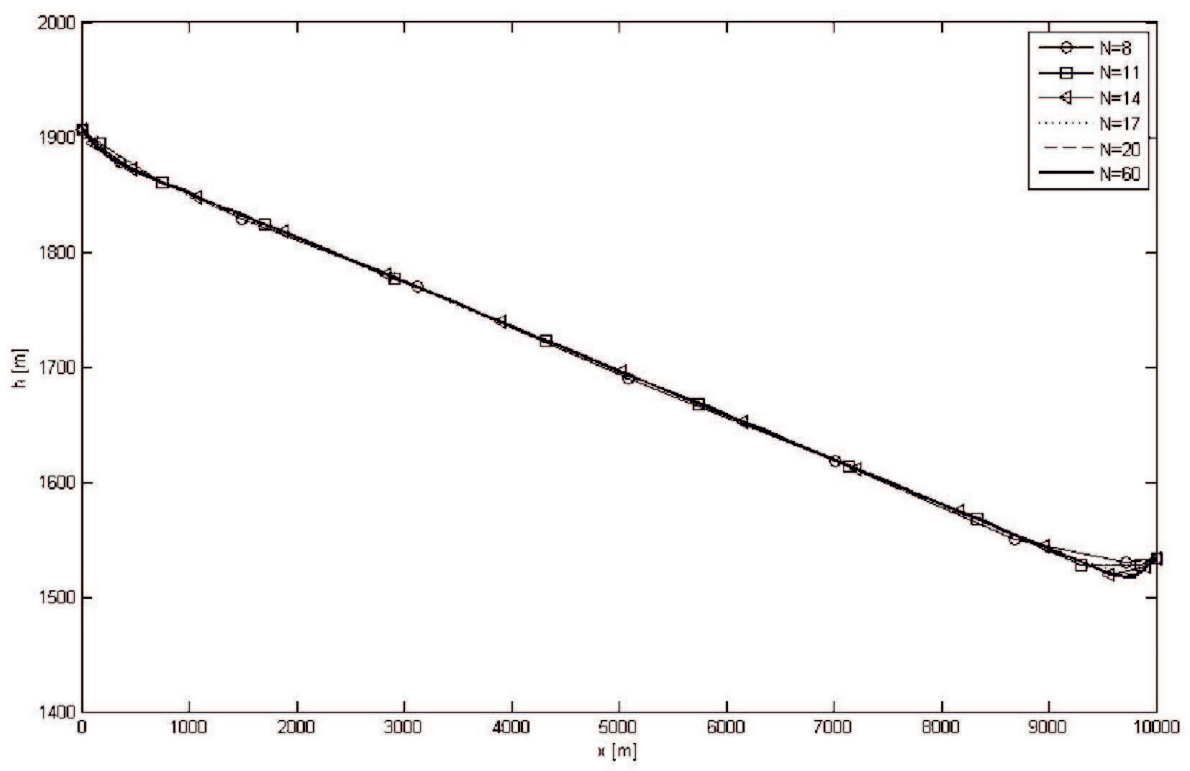

Fig. 4. Optimum altitude $\mathrm{h}$ versus covered distance $\mathrm{x}$ for different node number N. Still conditions

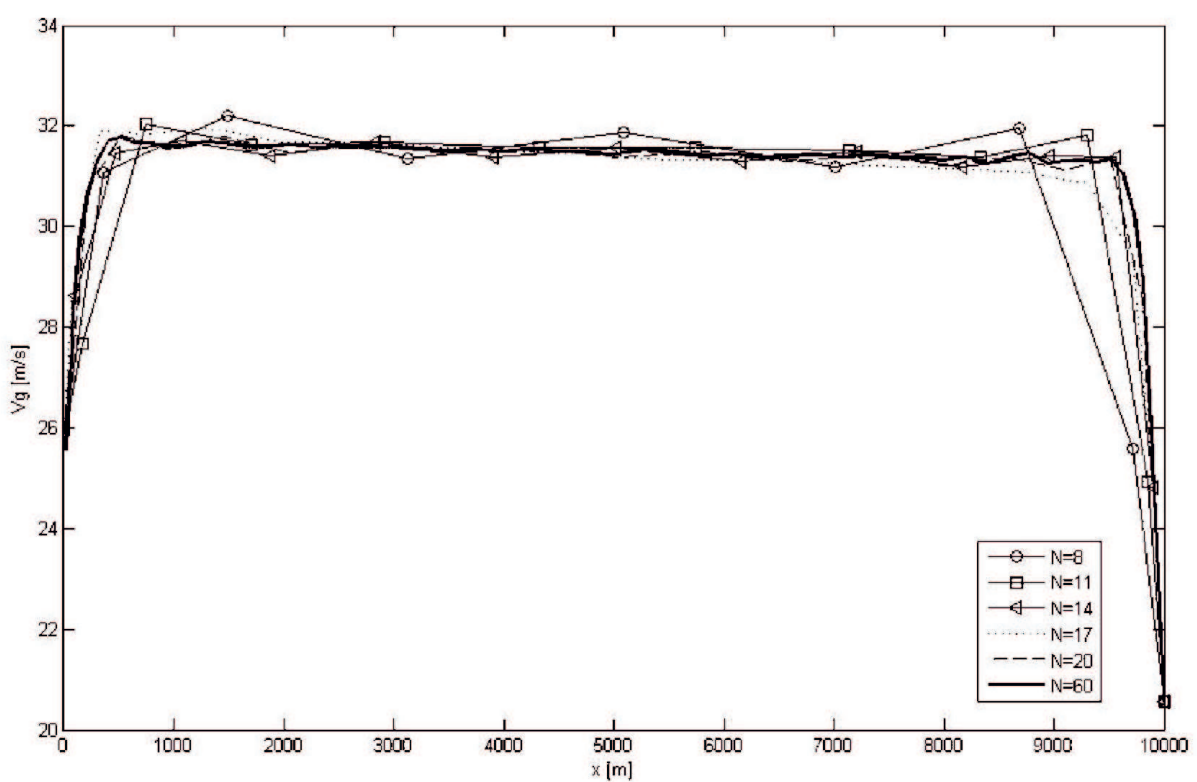

Fig. 5. Optimum glider's ground velocity $\mathrm{V}_{g}$ versus covered distance $\mathrm{x}$ for different node number N. Still conditions 


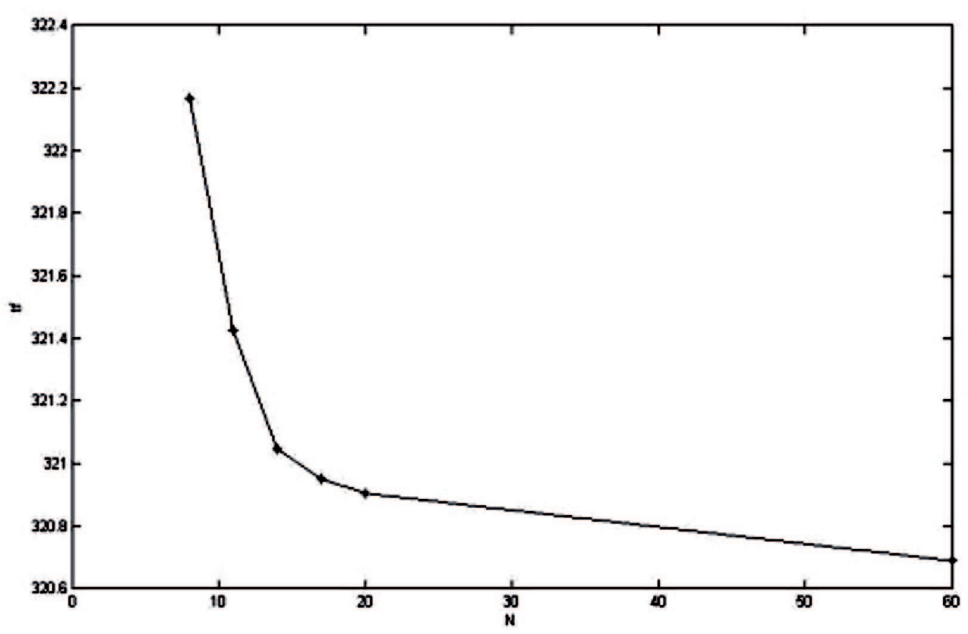

Fig. 6. Optimum time $\mathrm{t}_{f}$ (in seconds) of covering the distance $\mathrm{x}_{f}=10000 \mathrm{~m}$ (values of the performance index) versus node number N. Still conditions

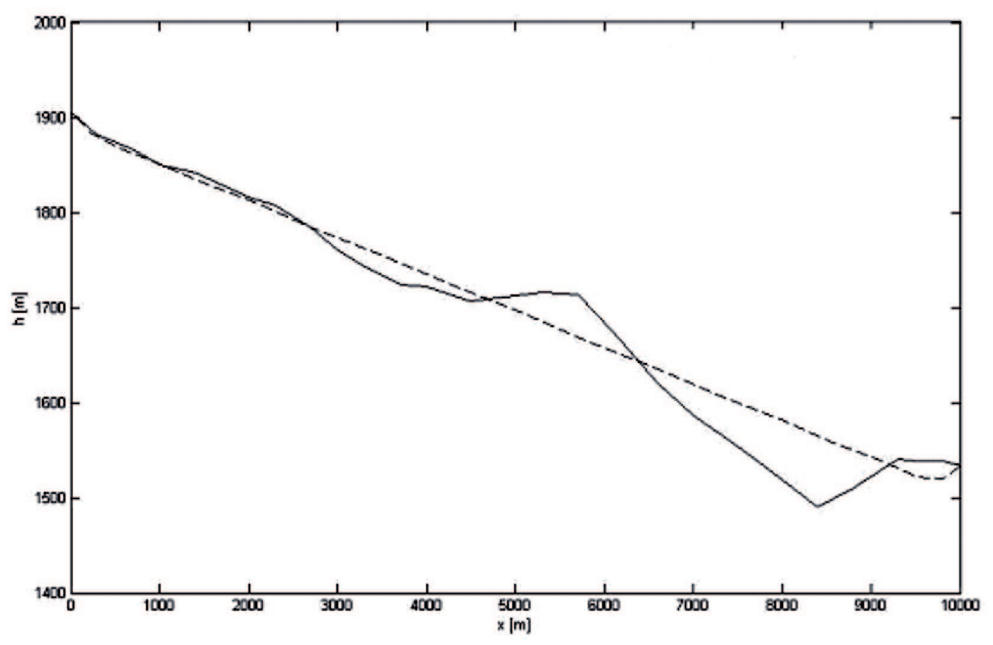

Fig. 7. Altitude h versus covered distance $\mathrm{x}$ for real (solid line) and computed trajectories (dashed line) 


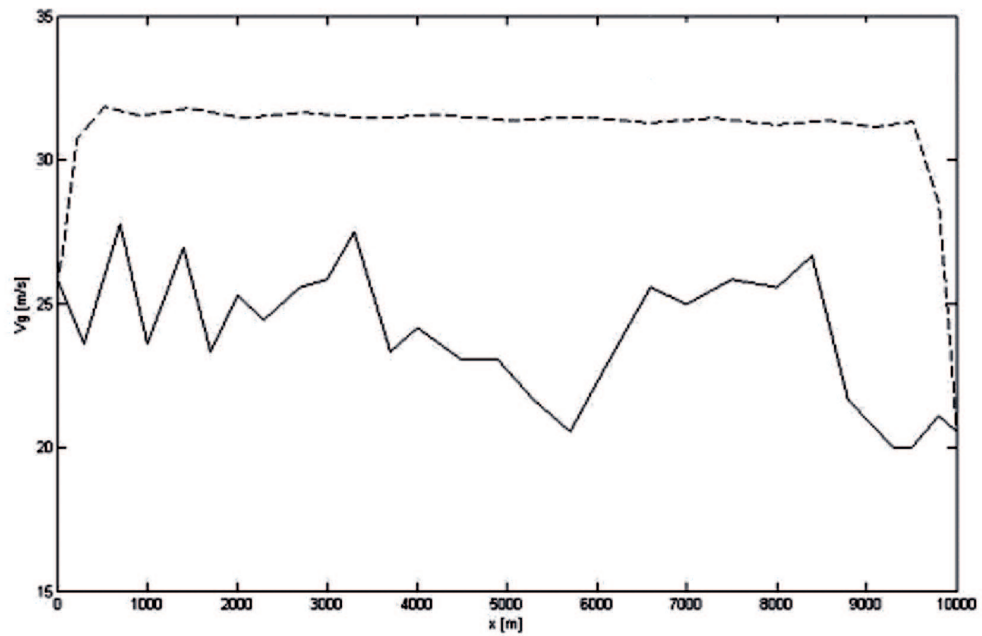

Fig. 8. Velocity $\mathrm{V}_{g}$ versus covered distance $\mathrm{x}$ for real (solid line) and computed trajectories (dashed line)

To analyze the influence of wind and current patterns on the glider's trajectory, we should consider different conditions. As an example, the trajectories for different values of horizontal component of the wind are given in Fig. 9 and Fig. 10. The greater average glider's velocities are obtained due to the tail wind.

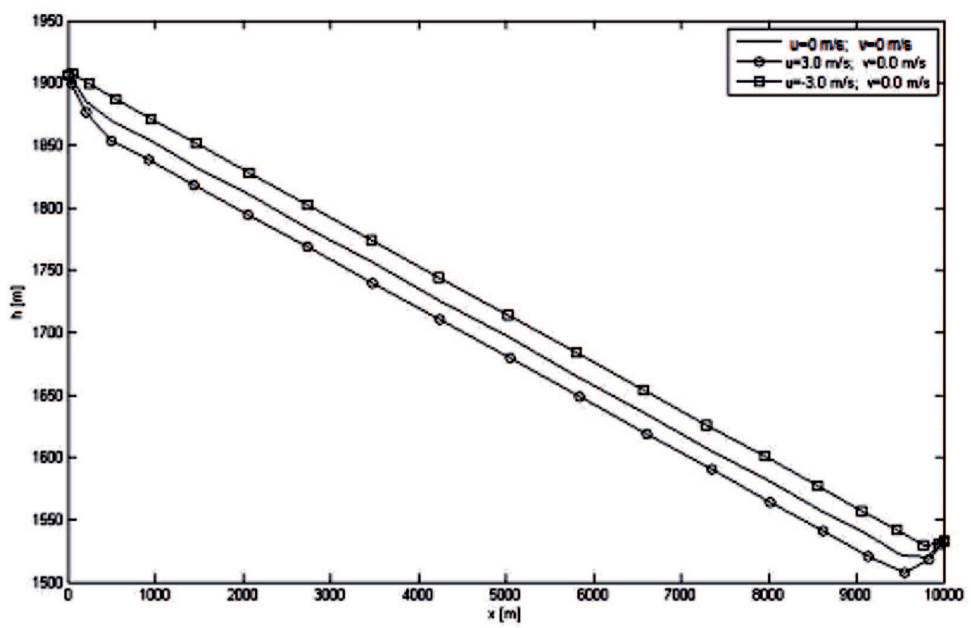

Fig. 9. Optimum altitude of flight $\mathrm{h}$ for different values of horizontal component of the air velocity $u(u=0, u= \pm 3 \mathrm{~m} / \mathrm{s})$ 


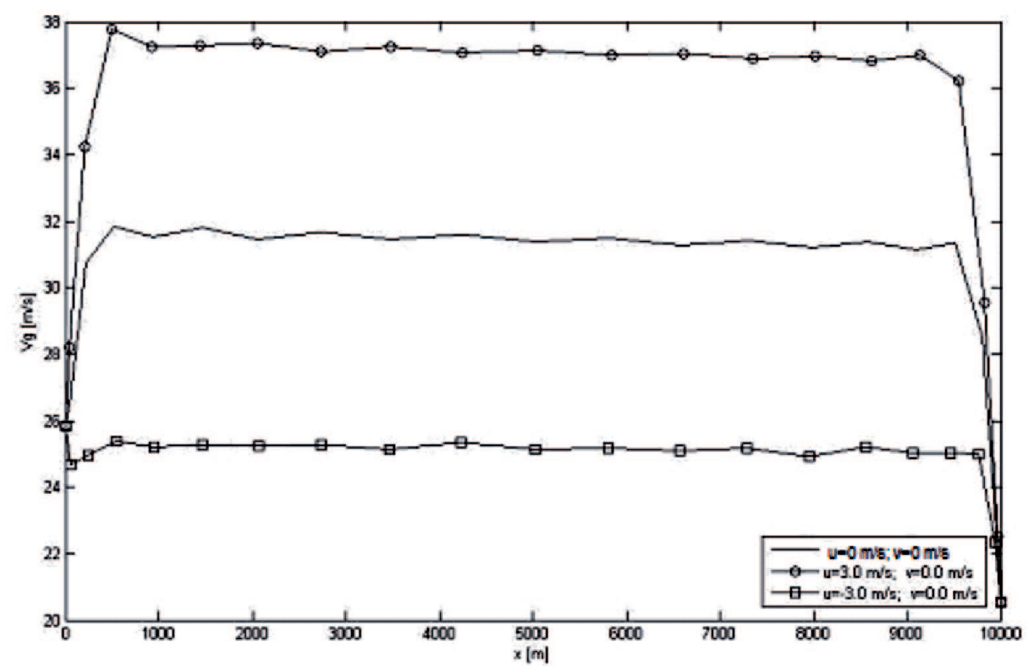

Fig. 10. Optimum glider's ground velocities $\mathrm{V}_{g}$ for different values of horizontal component of the air velocity $u(u=0, u= \pm 3 \mathrm{~m} / \mathrm{s})$

The presented approach confirms the well-known fact that the appearance of the climbing component of air velocity $\mathrm{v}$ is advantageous, and it gives a shorter time of covering the distance (Fig. 11, Fig. 12).

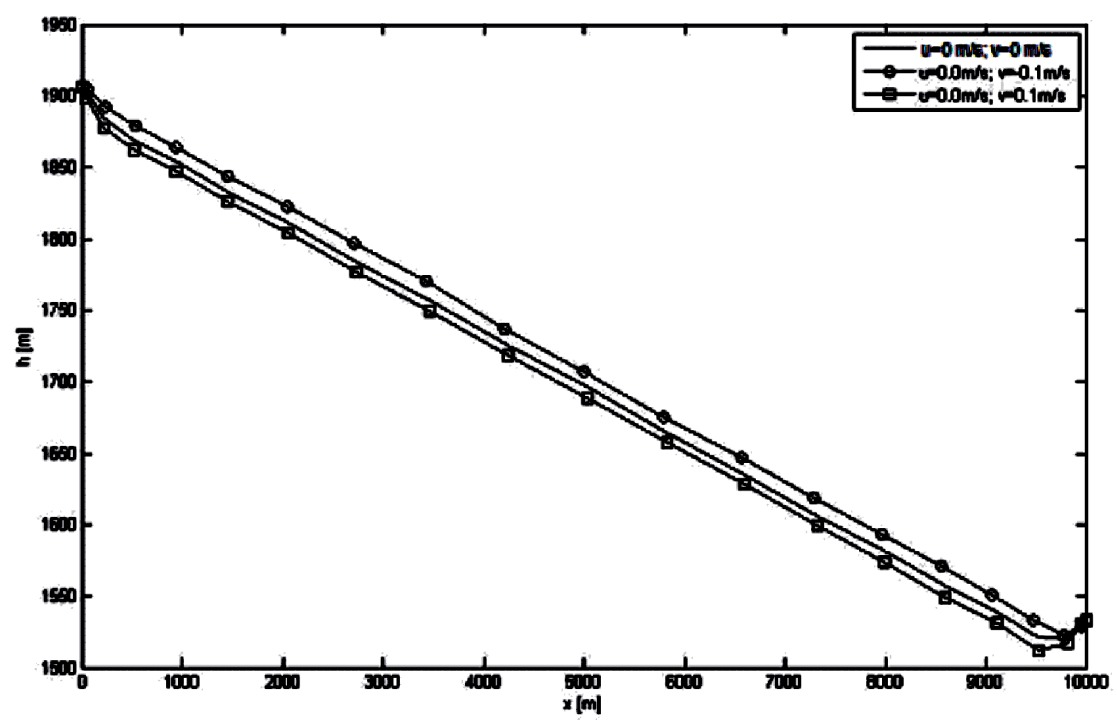

Fig. 11. Optimum altitude of flight $\mathrm{h}$ for different values of vertical component of air velocity $\mathrm{v}$ $(\mathrm{v}=0, \mathrm{v}= \pm 0.1 \mathrm{~m} / \mathrm{s})$ 


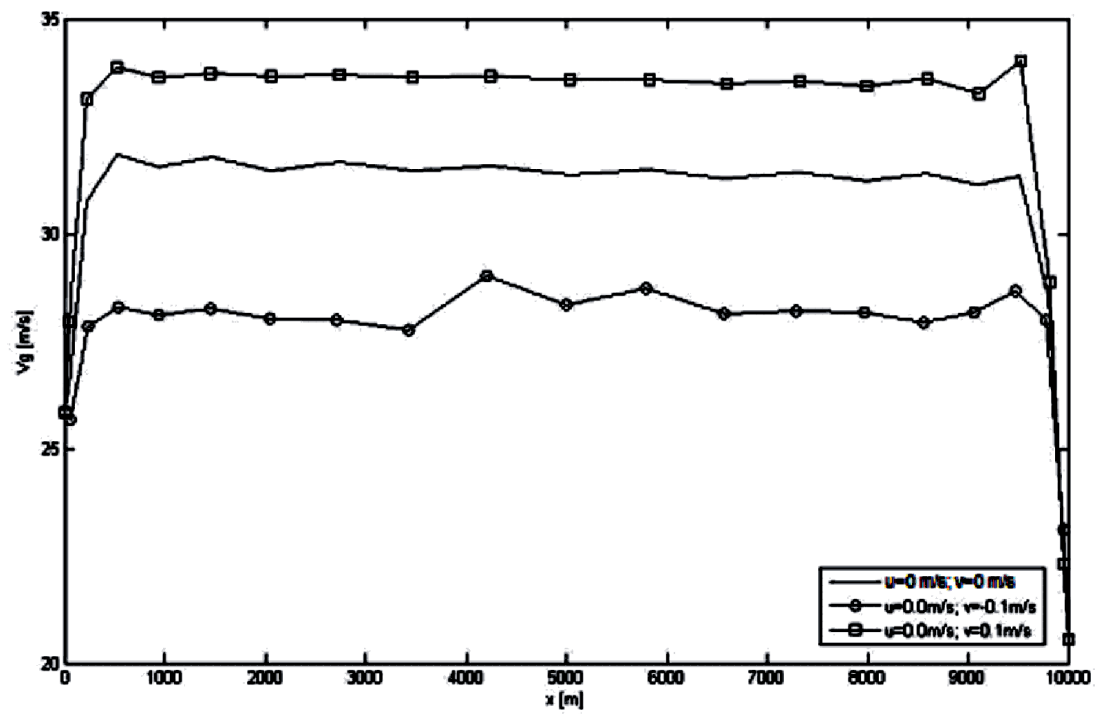

Fig. 12. Optimum ground velocity $\mathrm{V}_{g}$ for different values of vertical component of air velocity $\mathrm{v}$ $(\mathrm{v}=0, \mathrm{v}= \pm 0.1 \mathrm{~m} / \mathrm{s})$

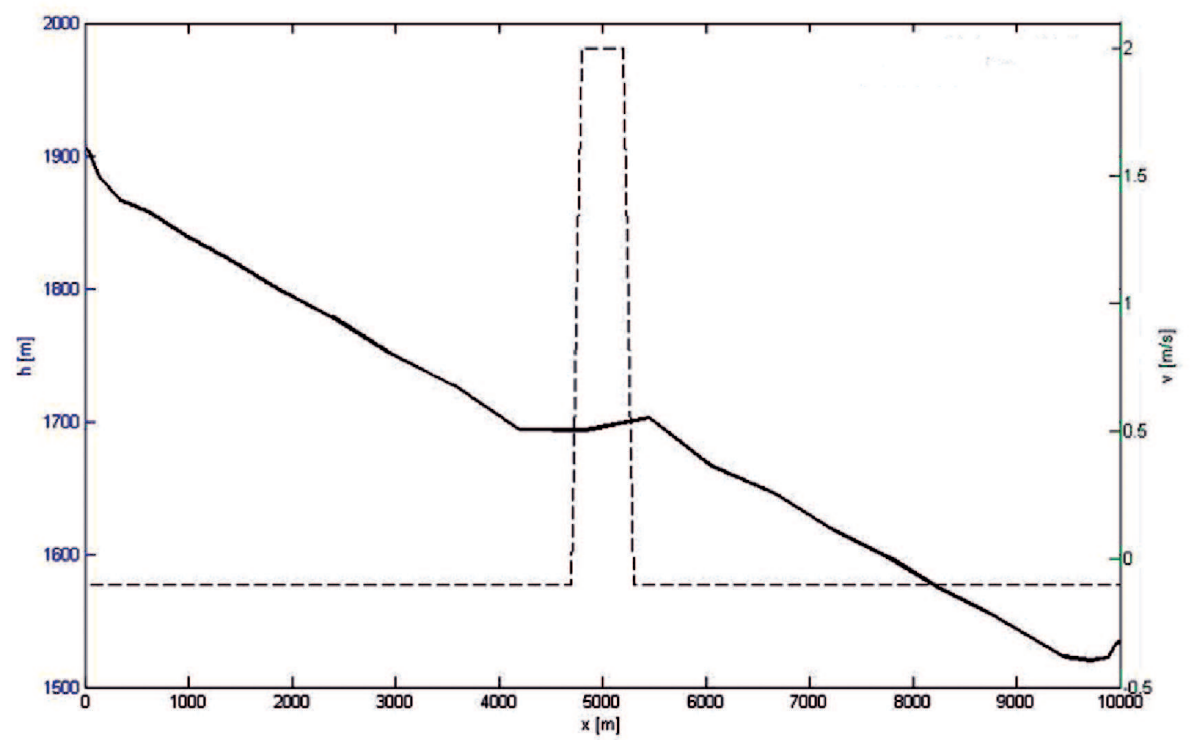

Fig. 13. Optimum altitude $\mathrm{h}$ versus the distance $\mathrm{x}$ for the thermal in the middle

In previous examples, the air components $\mathrm{u}$ and $\mathrm{v}$ are constant and don't depend on the distance. The method makes it possible to consider the local variations of wind conditions. Let's consider for example the descending 
component of air velocity $\mathrm{v}$ that has the same value over the distance except of the middle segment, where one encounters a climbing component representing the thermal (right hand scale in Fig. 13 and Fig. 14). The altitude $h$ and the ground velocity $\mathrm{V}_{g}$ versus the distance $\mathrm{x}$ are given in Fig. 13 and Fig. 14.

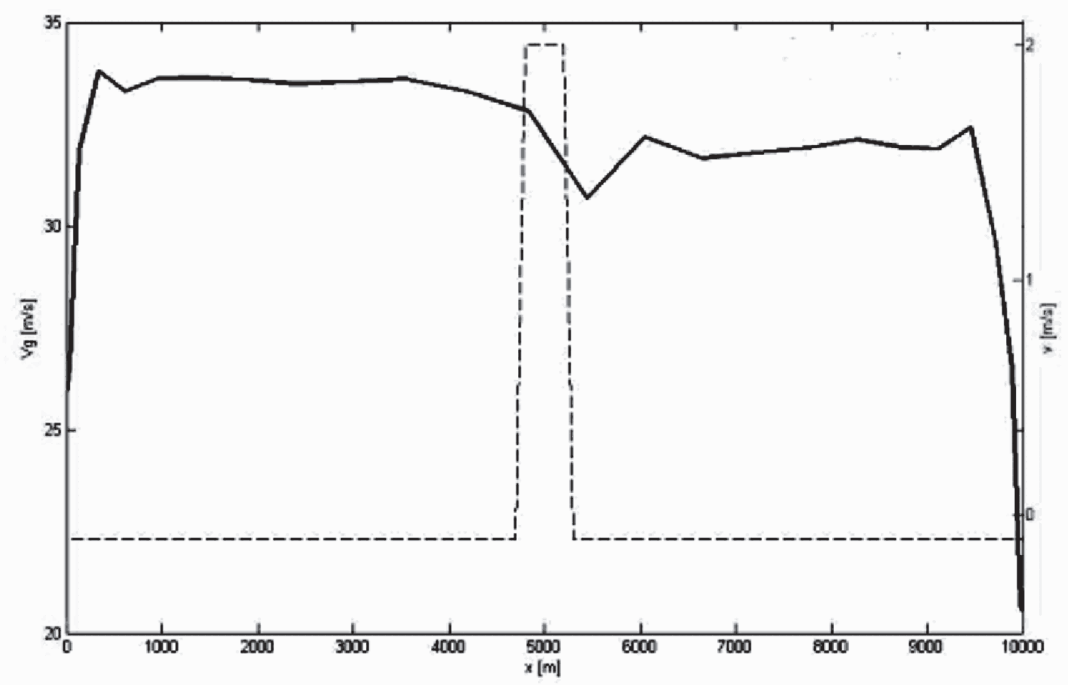

Fig. 14. Optimum ground velocity $\mathrm{V}_{g}$ versus the distance for the thermal in the middle

\section{Conclusions}

In this paper, we considered the minimum-time problem for the glider that moves in the vertical plane. Different wind and air current patterns were taken into account. The glider was regarded as a particle that moves under gravitational and aerodynamic forces. The problem has been solved using direct pseudospectral Chebyshev's method. The method is effective and flexible, which means that one can consider different constraints, including inequality ones, imposed onto the state variables. The method was implemented on a personal computer. The approach may be employed for evaluation of different glider's performances after variations of the input data, for example for examining the influence of variations of the mass of the glider on the time of covering the distance (Rogowski, 2007). The presented method is much more sophisticated than the classical one where the quasi-static model of glider's motion is considered, and the accelerations appearing on the lefthand sides of equations (2), (3) are neglected (Mozdyniewicz, 1976). In our 
approach, the potential energy of the glider may be converted into the kinetic one and vice versa.

Manuscript received by Editorial Board, September 08, 2010; final version, December 17, 2010.

\section{REFERENCES}

[1] Clancy L.J.: Aerodynamics, Pitman Publishing, 1975, London.

[2] Fahroo F., Ross M.: Direct Trajectory Optimization by a Chebyshev Pseudospectral Method, Journal of Guidance, Control, and Dynamics, 25, 1, 2002, pp. 160-166.

[3] http://zawody.aeroklub.suwalki.pl/kzs2006/wyniki.php (in Polish).

[4] Instrukcja użytkowania w locie szybowca PW-5 „Smyk”, Doświadczalne Warsztaty Lotniczych Konstrukcji Kompozytowych, B1-PW-5/IWL/I/2001, Warszawa (in Polish).

[5] Maroński R., Łucjanek W.: Optymalizacja trajektorii samolotu w locie na zadaną odległość, Archiwum Budowy Maszyn, 2, 1979, pp. 239-256 (in Polish).

[6] Maroński R.: Minimalizacja zużycia paliwa w locie na zadaną odległość, Mechanika Teoretyczna i Stosowana, 26, 3, 1988, pp. 541-556 (in Polish).

[7] MATLAB Optimization Toolbox. User's Guide, 2000, MathWorks.

[8] Mozdyniewicz W.: Loty falowe, WKŁ, 1976, Warszawa (in Polish).

[9] Obciążenia struktury szybowca PW-5 „Smyk”, Zespół Naukowo-Badawczy Lotniczych Konstrukcji Kompozytowych, Instytut Techniki Lotniczej i Mechaniki Stosowanej, Politechnika Warszawska, PW-5/0/II/93, 1993, Warszawa (in Polish).

[10] Panasz P., Maroński R.: Commercial aircraft trajectory optimization by a Chebyshev's pseudospectral method, The Archive of Mechanical Engineering, LII, 1, 2005, pp. 5-19.

[11] Rogowski K.: Optymalizacja trajektorii szybowca przy zadanym rozkładzie noszeń, Praca Dyplomowa Magisterska na Wydziale Mechanicznym Energetyki i Lotnictwa Politechniki Warszawskiej, 2007, Warszawa (unpublished).

[12] Rutowski E.S.: Energy approach to the general aircraft performance problem, Journal of Aeronautical Sciences, March 1954.

[13] Trefethen L.N.: Spectral methods in Mathlab, Society for Industrial and Applied Mathematics, 2000, Philadelphia.

[14] Zalewski A., Cegieła R.: Matlab - obliczenia numeryczne i ich zastosowania, NAKOM, 2002, Poznań (in Polish).

\section{Optymalizacja trajektorii szybowca dla zadanych warunków termicznych}

\section{Streszczenie}

Rozważono zagadnienie minimalno-czasowe ruchu szybowca w płaszczyźnie pionowej. Szybowiec jest modelowany jak uskrzydlony punkt materialny poruszający się $\mathrm{w}$ atmosferze przy zadanych warunkach termicznych. Zagadnienie zostało sformułowane za pomocą formalizmu teorii sterowania optymalnego. Rozwiązano je bezpośrednią pseudospektralną metodą Czebyszewa. Wykorzystano dane dla szybowca Klasy Światowej PW-5 „Smyk”. Wyznaczone trajektorie optymalne porównano z trajektoriami uzyskanymi w czasie Drugich Krajowych Zawodów Szybowcowych w Suwałkach w 2006 roku. 